\title{
ICELAND: THE BIRTH OF THE WORLD'S FIRST CROWD-SOURCED CONSTITUTION?
}

\section{Katrín Oddsdóttir}

\begin{abstract}
Following the country's devastating economic crash in 2008 and the liberal 'Pots and Pans Revolution' it precipitated, Iceland embarked on a novel, massively participatory constitutional drafting process in a bid to establish a new Constitution for the Nordic island nation. This involved a world-first use of 'crowd-sourcing' and social media to gather 'citizen generated content' in the final Draft Constitution. The Draft's current status is uncertain, however, as it has not yet been ratified by the Althingi, the Icelandic Parliament. This note, written from the perspective of a Rejkjavik public lawyer and one of the 25 Members of the Constitutional Council, tells the saga of the world's first crowd-sourced constitution, the social and economic environment in which it was conceived, and speculates as to the circumstances which might lead to its revival.
\end{abstract}

\section{Keywords}

Iceland, Constitutional Assembly, Ratification, Economic Crisis

\section{Introduction}

This note tells the story of the drafting of a new constitution for Iceland in the aftermath of the financial crisis of 2008. It is told from the perspective of the author, one of 25 elected members of Iceland's Constitutional Council, which operated in 2011. It presents a first-person account of the constitution-drafting process and its unique circumstances, which has attracted some comparative interest. Attempting a constitutional transition in the aftermath of an economic disaster of unprecedented scale, the Constitutional Council drafted a new constitution in an effort to design rules for the tiny Nordic nation which would, among other things, minimize the chances of such an economic disaster recurring. The approach taken by the Constitutional Council to creating the draft was unprecedented and innovative, especially as an attempt, perhaps for the first time in the history of a nation-state, for a foundational text to be written with the more or less direct participation of its people. ${ }^{1}$ Historically, processes of

${ }^{1}$ H Landemore, 'Inclusive Constitution Making: The Icelandic Experiment' (2014) J of Political Philosophy (early online view), 2.

Copyright $\odot$ the Author(s).

This work is licensed under a Creative Commons Attribution-NonCommercial-NoDerivs 3.0 License. 
constitution-writing have generally tended to be elitist and secretive. The draft Icelandic constitution was generated in a massively transparent process, making active use of such tools as social media. The public was invited to join actively in the drafting process itself, simulating 'crowd-sourcing' techniques, familiar mostly in computer programming to that date.

Despite the draft being approved by $2 / 3$ of votes in a (non-binding) national referendum, it has not been implemented; the bill requires parliamentary approval to take effect, but has been 'shelved' by the Icelandic Parliament, the Althingi. Many remain doubtful whether it ever will pass into law. Nevertheless, this democratic process of constitutional design, utilising tools in communications and social media, could signal a new approach to the making of constitutions, and perhaps other legislation. The working methods of the Constitutional Council that captured the world's attention are of continuing interest to comparative constitutional studies despite the draft constitution's current uncertain status.

\section{Background}

Iceland is a peculiar place in many respects. Located in the middle of the Atlantic Ocean, midway between Europe and America, the tiny population of 330,000 is highly homogeneous, and prides itself on a high level of literacy and general education. Internet connectivity is among the highest in the world.

Iceland's democratic republic was founded in 1944 when Icelanders unilaterally declared independence from then Nazi-occupied Denmark. In the effort to achieve a smooth transition, emphasis was put at the time on forging a united stance among the citizens of Iceland on the issue of independence, and potentially contentious matters such as drafting a constitution were left to wait for a more suitable time. ${ }^{2}$ The Danish Constitution of 1849 was taken as the model for Iceland's first constitution as an independent state. Despite it being firmly stated that a domestic constitution should be written for Iceland following independence, the Icelandic republic still rests on a modified translation of the 1849 Constitution of the Danish constitutional monarchy. ${ }^{3}$

Two important changes were made to this Constitution at the outset. First, the President of the new republic was to be elected by the public and not by

\footnotetext{
${ }^{2}$ Compare this to the incomplete Israeli Basic Law, and the failure by the Federal Republic of Germany to update its interim Grundgesetz following reunification.

3 See Constitution (Republic of Iceland), Act No. 33/1944.
} 
Parliament, ${ }^{4}$ which gave Iceland the first popularly elected President in Europe. Secondly, the President was given the power to veto legislation from Parliament by refusing to sign it. Rather than preventing a bill passing into law, exercises of the presidential veto trigger a national referendum on the issue to ratify the law against the presidential veto. ${ }^{5}$ (This provision was triggered in the political crisis that followed the 'Icesave' controversy, discussed below). Besides these two important changes, the Constitution has been updated to a minor extent a few times since its establishment, mostly in order to change voting constituencies and matters relating to general elections. The most extensive change was made in 1995, when a new human rights chapter was written into the Constitution. The extensive changes promised at the birth of the republic, however, never came to fruition.

\section{3 'The Crash'}

In 2008, Iceland experienced an economic downfall so extensive that it has become known in the country simply as 'the Crash'. All major national banks collapsed, and the country entered into a deep financial and economic crisis. This received global attention, as it reflected the economic difficulties experienced across the world at the time. Overnight Iceland became the canary in the coal-mine, and its survival would indicate if other small European economies would leave the mineshaft alive. Emergency measures were passed to protect domestic depositors from the systemic failure. Despite these measures, the national economy suffered massively. The country became involved in diplomatic tensions with foreign governments-particularly the United Kingdom and the Netherlands-over the loss of foreign deposits with Icelandic banks. A series of bills precipitated a political crisis, as the presidential veto was exercised and referenda were called on the question to what extent (and for how long) the nation should assume the newly nationalized banks' debt. ${ }^{6}$

The downfall in Iceland was not only economic-it was also political and moral. The rather wealthy society had believed that relatively little corruption existed within the Icelandic administration and political landscape. The immense

${ }^{4}$ Ibid, Art 3.

5 See ibid, Art 26. See also T Gylfason, 'Constitution on Ice', Working Paper No 5056, Centre for Economic Studies and Ifo Institute, November 2014, <https://notendur.hi.is//gylfason/cesifol_wp5056.pdf> [accessed 9 December 2014].

${ }^{6}$ For a history and analysis of the Icelandic crisis, see generally E Bergmann, Iceland and the International Financial Crisis: Boom, Bust, and Recovery (2014). 
growth of the country's banking system-which had grown in the years of the economic boom to around ten times the nation's annual GDP-had been perceived as something to be proud of, traced to the brilliance of young Icelandic bankers. This made the downturn all the more traumatic for the Icelandic society. And the scale of the disaster was unprecedented-the sums of wealth destroyed in the crash were equivalent at the time to seven times the country's annual GDP. ${ }^{7}$ It was the first, spectacular collapse of the global financial crisis-the first of many, with Ireland, Greece, Cyprus, and others soon to follow, and the Eurozone debt crisis still threatening to undermine the stability of the European Union as a result.

The anger experienced by a broad cross-section of the Icelandic public was largely based on a sense of betrayal by political and economic elites. It was widely perceived that elected politicians had participated in creating a 'smokescreen', which made the growth of unsafe banking practices possible. The people took to the streets in mass protests. This sort of mass protest remains unique in the history of this relatively young democracy, both in the number of participants and in the manner in which the protests took place, followed only by the 1949 protests against Iceland entering NATO. People young and old, from all walks of life, armed themselves with pots and pans used to create a rhythmic beat to the loud, repeated chant demanding the government to resign. The series of protests have been named the 'Pots \& Pans Revolution' as a result. January 2009 saw the Althingi surrounded by thousands of people, and unprecedented mass arrests.

Eventually, the protests became too loud to ignore, and the Government acknowledged that reform was necessary. The April 2009 parliamentary election produced a majority government excluding both the Independence Party and the Progressive Party which had, separately or in coalition, governed Iceland virtually without interruption throughout the history of the Republic. ${ }^{8}$ The new Government faced the momentous task of dealing with the consequences of the Crash.

\footnotetext{
Gylfason, above n 5. By way of comparison, the Darien Disaster, which triggered a series of economic problems in Scotland in the late $17^{\text {th }}$ century, and arguably led to the demise of the Kingdom of Scotland and the creation of the United Kingdom, destroyed about 25\% of the country's capital. See P W J Riley, The Union of England and Scotland: A Study in Anglo-Scottish Politics of the Eighteenth Century (1978), 35, 199; I McLean, What's Wrong with the British Constitution? (2010) 65.

${ }^{8}$ Gylfason, above $\mathrm{n} 5$.
} 


\section{Reactions}

The Crash provoked a number of political and institutional responses aimed at preventing a similar failure in the future, of which five are discussed here. First was the establishment of a Special Prosecutor's Office, which grew from 3 to 100 employees almost overnight. This was to some extent due to the advice of Eva Joly, a Norwegian-born French investigative judge specializing in corruption and economic crimes, who was appointed as a consultant to the newly elected government. The Office prosecuted senior bankers, public servants, and others on charges such as insider trading and market manipulation. Some of the charges lead to sentences, and others to acquittal. Many decisions still await a final verdict in the Supreme Court. Nevertheless, a certain importance is linked to the investigation of the acts that lead to the crisis and their referral to the judicial system, as similar acts have gone widely unpunished in other countries. Also noteworthy is the fact that the court system seems to have handled the caseload being brought before it, unprecedented both in scale and matter, quite well.

Secondly, a Special Investigation Commission appointed by the Parliament published its 2,400-page report in 2010 outlining flaws in the system as a whole and describing the legal violations and acts of recklessness by private and public actors, as well as academics and media, which contributed to the disaster. ${ }^{9}$ In a society as small as Iceland, the detail of this report and its level of scrutiny should not be underestimated.

Thirdly, the Prime Minister at the time of the Crash, Geir Haarde, was tried and sentenced for negligence in his official capacity in the Landsdomur in 2011, in the first time the special tribunal was convened in the nation's history. ${ }^{10}$ He has referred that verdict to the European Court of Human Rights, and the case has not yet been heard, but this approach to negligence in the conduct of high office is certainly unique.

Fourthly, the double national referendum on the Icesave bills established limits to the population's liability for debts to guarantee foreign deposits with Icelandic banks. In both referenda, the Icelandic public refused to shoulder such responsibility, and the legal soundness of this refusal has been confirmed by the EFTA Court, which on 28 January 2013 cleared Iceland of all charges in this

${ }^{9}$ See Rannsóknarnefndar Alpingis, Report of the Special Investigation Committee, Reykjavik, 12 April 2010, <http://www.rna.is/eldri-nefndir/addragandi-og-orsakir-falls-islensku-bankanna2008/skyrsla-nefndarinnar/english/> [accessed 7 November 2014].

${ }^{10}$ See Landsdómsmálið Nr. 3/2011, Alpingi gegn Geir Hilmari Haarde, <http://www.landsdómur.is/um-landsdom/frettir-og-tilkynningar/nr/71> [accessed 3 December 2014]. 
regard. ${ }^{11}$ The Court rejected the claim that Iceland had breached the Deposit Guarantee Directive or had discriminated against depositors contrary to EEA law.

Fifthly, and most relevantly for the purposes of this note, was the appointment of Iceland's Constitutional Council in 2011. Along with many others, the author had participated actively in the protests in 2008 and 2009. A law student at the time, I delivered a speech at one of the organized protests, ${ }^{12}$ which gained significant attention among the public and in the media. Following that speech, I was elected as one of the 25 members of the Constitutional Council in a general election in 2010.

My position in taking a place on the Constitutional Council-the position which had found so much resonance in the Icelandic constituency-was that the process of amending the Constitution was reflective of an underlying power struggle within the Icelandic nation since the establishment of our republic. This struggle relates to the abundance of natural resource wealth and relatively insular political leadership: political elites manage resource ownership and wealth, and though they are meant to do so for the benefit of the people who hold indirect ownership over those resources, the lack of democratic control means that political elites can become divorced from their constituents. ${ }^{13}$ This underlying struggle, in turn, may explain the situation of the draft new constitution: according Art. 79 of Iceland's current Constitution, the Constitution can only be changed if Parliament accepts the changes before announcing a new general election, and the new Parliament thereafter confirms the changes. This makes constitutional amendment difficult, as it gives political elites the opportunity for filibustering and horse trading, making the amendment process highly vulnerable to politicking in the last days of each parliamentary session.

${ }^{11}$ Case E-16/11, EFTA Surveillance Authority $v$ Iceland (EFTA Court, 28 January 2013) <http://www.mfa.is/media/icesave-2011-12/16_11_Judgment-Icesave-Case.pdf> [accessed 10 November 2014]. For the background to the Icesave dispute, see e.g. M E Méndez-Pinedo, 'The Icesave Dispute in the Aftermath of the Icelandic Financial Crisis: Revisiting the Principles of State Liability, Prohibition of State Aid, and Non-Discrimination in Europe' (2011) 3 European J of Risk Regulation 356.

$12<$ https://www.youtube.com/watch?v=aE-t_hSZojE> [accessed 20 January 2015].

13 The Venice Commission took notice of the 'crisis of trust' in the Icelandic 'population vis-a-vis the political class and, by extension, the institutions' following the Crash. See Opinion No 702/2013, Venice Commission Opinion on the Draft New Constitution of Iceland (11 March 2013), para 12. 


\section{The preparation for the writing of a new Constitution}

A unique atmosphere was palpable after the Crash in Iceland. There was a widespread desire to change the society in order to prevent similar things from recurring. Bruce Ackerman's notion of a 'constitutional moment' is apt to describe it-it was a period in which matters of constitutional politics captured the attention of the public, ${ }^{14}$ and the aspiration behind the new constitution was that Iceland's liberal 'pots and pans revolution' would crystallise into a new social, political, and economic order. ${ }^{15}$

I remember the very special atmosphere of excitement and unity, despite underlying tension, in late 2008 and 2009. People debated in the media and amongst themselves about big and important issues more than ever before. Suddenly, the average person found herself diagnosing complex economic situations over coffee with friends, and cracking faults in legislation at family dinners. One of the recurring themes at such occasions was the Constitution. The perception was widely held that Iceland needed its own social contract, as had been promised from the foundation of the republic, to replace the Danish legacy document.

The way forward chosen by the Government at the time was to appoint a seven-member Constitutional Committee, comprised in the first instance of a broad range of academic experts. The role of the Committee was threefold-first, to organize a National Assembly of 1000 randomly selected members of the public, who would outline the sort of values on which the nation wanted to build its new social contract. Secondly, to prepare a nationwide election of 25 representatives to a Constitutional Assembly, whose task would be to draft a new constitution building on the views of the National Assembly. Thirdly, to prepare the ground for the Constitutional Assembly by offering analysis of the 1944 Constitution and gathering available academic material about local and international constitutional matters.

Consisting of 950 randomly selected individuals of all ages and from all segments of society, the National Assembly met for a day in early November 2010. It issued a set of conclusions stating that a new Constitution was called for, and that it needed to contain provisions on national ownership of natural resources, foster accountability, facilitate the decentralization of power, ensure

\footnotetext{
${ }^{14}$ See B Ackerman, We The People: Foundations (1991) 31.

${ }^{15}$ See B Ackerman, The Future of Liberal Revolution (1994) 46.
} 
environmental protection, and so forth. All the output of the National Assembly was made accessible to the public online. ${ }^{16}$ The Assembly was also live streamed online on the day of event. The results were summarized and rendered into a 'mind map' made publicly available. A generous budget was allotted to bring together randomly selected individuals for a one-day exercise in brainstorming and discussion of main ideas to be included in the constitution. Despite being quite general, and at times even paradoxical, most of the Forum's conclusions arguably reflected the views of the population of Iceland. Among them were the importance of human rights, democracy, transparency, equal access to healthcare and education, as well as a desire for a more strongly regulated financial sector and for putting Iceland's natural resources under public control..$^{17}$

The next step was taken in late November 2010, when elections were held to select the 25 representatives on the Constitutional Council. As laid down by Act No. 90/2010 on the Constitutional Council, the role of the Council would be to draft a new Constitution for Iceland. Every Icelandic person 18 years of age and older was eligible to run for the elections, apart from the President of Iceland, Ministers, members of the Constitutional Committee and Supreme Court judges. Despite the fact that 'reform fatigue' had started to set in at that time, 522 candidates came forward, each supported by between $30-50$ signatures. Considering Iceland's small population of only 330,000 people, and an eligible population of about 250,000, this is remarkable: about one in 500 eligible citizens put themselves forward for election, and about one in 15 people endorsed a candidate with their signature.

The 25 members of the Council were elected in vote with a 37\% turnoutwhich is relatively low on Icelandic standards, which tend to be more than $80 \% .{ }^{18}$ However, the elections were considered complex because of the numerous candidates and the uniqueness of the topic, which might explain the low turnout. On the up side, it was clear that there was no need to use legal provisions for adding members to even out the participation of men and women: the Constitutional Council consisted of 15 men and 10 women, almost all of whom had little to no prior political experience in conventional terms. The members were quite diverse, although five of them were professors and three junior academics, making the academy more represented than the general public.

\footnotetext{
${ }^{16}$ For the National Assembly's website: <http://www.thjodfundur2010.is.heim/> [accessed 2 December 2014].

${ }^{17}$ Landemore, above n 1, 7-8.

${ }^{18}$ See 'Voter turnout data for Iceland', International Institute for Democracy and Electoral Assistance, $<$ http://www.idea.int/vt/countryview.cfm?CountryCode=IS $>$ [accessed 7 November 2014].
} 
Shortly afterwards, the Supreme Court of Iceland deemed the elections void due to technical errors, although there was no evidence that the alleged errors had led to any substantive problems with the result of the ballot. ${ }^{19}$ As no question existed as to the substantive outcome, the Parliament appointed the members-elect so that the work would not be delayed further.

\section{Methodology}

As Landemore has observed, the unique inclusiveness which symbolized the methodology used to draft a new Icelandic constitution involved three different and complementary methods: (i) direct popular participation at various stages of the process, (ii) elements of descriptive representativeness where direct participation wasn't possible, and (iii) transparency. All three aspects arguably combined to ensure not just procedural legitimacy, but also some degree of epistemic reliability. $^{20}$

The Constitutional Council of Iceland had only four months to write a new constitution. The recently published 700-page report from the Constitutional Committee proved to be very helpful to speed the work of the Constitutional Council, but more was needed if the task was to be completed on time. It was decided that, for the sake of both speed and credibility, the Constitutional Council would work in as transparent a manner as possible. Relying heavily on online social media and technology such as Facebook, Youtube, and Twitter, we aimed to represent the sort of change which we requested from other public servants in our proposed draft. All general meetings of the Constitutional Council were broadcast live on its website. Every week a new draft of the constitution was put online, allowing the general public to comment on the most recent changes using their own Facebook-accounts. All in all, the draft was posted online twelve times at various stages of completion. The draft was therefore created in an incremental way, and while there was not a stated conscious intention on the part of the Council members to establish a systematic back and forth between the Council and the crowd, something close to a feedback loop emerged from the very first draft onwards. The first draft contained only the main 'headings' or 'chapters'.

${ }^{19}$ See 'The judgment of the Supreme Court of Iceland', 25 January 2011, <http://www.haestirettur.is/control/index?pid=1109> [accessed 7 November 2014]. For an English language media summary of the decision, see 'News Review: The Supreme Court's Verdict', Iceland Review Online, 26 January 2011, <http://icelandreview.com/news/2011/01/26/news-review-supremecourts-verdict> [accessed 7 November 2014].

${ }^{20}$ Landemore, above n 1,3 
Once the structure was exposed to comments, the Council proceeded to integrate some of the remarks and write up the actual text corresponding to each 'heading'. The text was fleshed out progressively, and responsively, over several iterations of the same process. Feedback from the public was received and assessed by Council members. Useful feedback would shape and inform the next draft which would then be published online, and so on. ${ }^{21}$

The Council also invited the public, including experts and stakeholders, to send briefs with their ideas and suggestions during the drafting process. All of those suggestions were discussed by the relevant sub-committee of the Council, and some became part of the final document. Internet penetration is very high in Iceland and therefore a lot of ideas and suggestions were delivered through the Council's website and by email. However, the Council also received handwritten proposals, and these were processed the same way as other material. Some of the ideas and suggestions came from other countries, but, as the language of the process was Icelandic, most of the material received was in that language. This methodology of producing content resembles an idea mostly used in computer science known as 'crowd sourcing. The essence of such philosophy is the accumulation of knowledge through completely open processes. ${ }^{22}$

The results were quite amazing, as the comments and proposals received were almost without exception both useful and respectful. At the beginning, we had feared that the uncivilized tone to which online debate often descends would taint the work. However, such concerns proved totally unnecessary. The people repaid the trust they were shown by allowing open dialogue in a profound way, lifting the work and the outcome to a higher level than would ever have been possible for the 25 Council members with our limited time, resources, and staff. It is my conclusion, after participating in this project, that the wisdom of the crowd is profound, and should not be underestimated. Further, this methodology also provided legitimacy and 'ownership' of the project by those who participated. And as a consequence, by giving every person an equal opportunity to have a say, this process meant that when certain persons, for example experts, criticised the finished document, it was hard for them to explain why they did not rather

\footnotetext{
${ }^{21}$ On the substance of the draft, see Z Elkins, T Ginsburg, and J Melton, 'A review of Iceland's draft constitution' (2012) Constitutional Review: Iceland 2012, <http://comparativeconstitutionsproject.org/wp-content/uploads/CCP-Iceland-Report.pdf > [accessed 5 November 2014]. For information in English and a translation of the bill, see 'The Constitutional Council hands over the bill for a new constitution', Stjórnlagarád, 29 July 2011, <www.stjornlagarad.is/english > [accessed 7 November 2014].

${ }^{22}$ See D Brabham, 'Crowdsourcing as a Model for Problem Solving' (2008) 14 Convergence 75.
} 
participate in the process than criticize its result post hoc. It has to be stated, however, that a lot of local experts participated in writing the new draft with the Council, either as volunteers or by request of the Council.

Insufficient research exists on the methodology of this drafting process, including insufficient critique. Professor Ragnhildur Helgadottir is one of the scholars who has written extensively about this project. In a recent article, she points out that only $13 \%$ of the online submissions on the Constitution came from women, while $77 \%$ were from men and $10 \%$ from organizations. ${ }^{23}$ Helgadottir's preliminary work on this issue shows that we should still take pause to reflect critically on the process: first, most of the commentators were aged between 40 and 65 . While it is positive that older people were not excluded by the online medium, this is not an underrepresented constituency in normal public participation mechanisms, either. Furthermore, very few foreign citizens made suggestions via the website. Based on these findings, Helgadottir finds the crowd-sourcing process to have empowered Icelandic born middle-age males first and foremost-by no means an underrepresented group in traditional Icelandic politics. She says this finding may suggest 'that expectations towards informal mechanisms for public participation should be kept in check; they are not a clear solution for groups that are underrepresented in traditional politics, they can hardly replace more traditional mechanisms completely and a multiplicity of consulting mechanisms may be best. ${ }^{24}$ Adding my anecdotal experience to this line of criticism, it also seemed that the people who participated in the online dialogue were a self-selecting cohort, that is generally more interested in topics such as the freedom of speech and the Internet, than the members of the general Icelandic public. This is a matter to be addressed by constitutional process designers wishing to emulate the Icelandic crowd-sourcing model in the future.

Despite such limitations to 'Web 2.0 constitutional drafting', it remains clear that the Icelandic methodology is ground-breaking in a number of ways, which make it interesting for the comparative study of constitutional transition. Landemore observes that, throughout history, the actual writing of constitutional texts has been the most secretive moment in the history of constitutions-as

\footnotetext{
${ }^{23}$ R Helgadottir, 'Which Citizens? - Participation on the Drafting of the Icelandic Constitutional Draft of 2011' IJ Con L Blog, 7 October 2014, <http://www.iconnectblog.com/2014/10/whichcitizens-participation-in-the-drafting-of-the-icelandic-constitutional-draft-of-2011/> [accessed 5 November 2014].

${ }^{24}$ Ibid.
} 
was the case, for example, of the 'Founding Fathers' in the United States. ${ }^{25}$ She argues that the Council's use of crowd-sourcing was particularly striking in that it is both a recent technique and a deeply unconventional way of writing a constitution. While crowd-sourcing has become a popular tool to engage people in a wide variety of processes-ranging from urban planning to solving complex scientific problems-it had never been applied to a task as seemingly complex and momentous as the process of writing a new constitution. ${ }^{26}$ She also points out that the transparency of the methodology means that the public was able to witness, observe, and thus make up their minds about the activities of the actors engaged in the constitution-writing process. 'It would be hard to overstate the novelty of this transparency, especially in comparison with recent constitution-writing processes, such as the European or the Egyptian one', Landemore argues. ${ }^{27}$

Another characteristic element of the Constitutional Council's methodology was its emphasis on striving to reach consensus rather than using binding majority decision-making procedures. Many of the core issues addressed by the Council could have been resolved with a vote in the first few days of the work. However, it was decided that, instead of using such methods, consensus would be sought in as many cases as possible. This proved to be very successful, in my opinion; a number of matters which seemed to have only two possible solutions at first were examined from different and new perspectives, often providing a third way which was better than the first two in the opinion of both sides to a disagreement. After witnessing the power of consensus-building, it became evident that the standard democratic process which entails a majority overriding the minority on strength of numbers possibly still rests on a zero-sum paradigm of binary victory and defeat. By using this method, the Council managed what was thought by many to be inconceivable; that is to reach a unanimous decision on the final draft to a new Icelandic Constitution in a short space of time and with broad-scale public input. Bearing in mind how different the members of the Council were, that was an achievement which could never have been obtained without using consensus as a basis for collective decision-making-aiming for a solution to suit everybody, even those one disagreed with wholeheartedly. The draft was handed to the Althingi by the members of the Constitutional Council on 29 July 2011.

\footnotetext{
${ }^{25}$ Landemore, above $\mathrm{n} 1,2$.

${ }^{26}$ Ibid, 10.

${ }^{27}$ Ibid, 15-6.
} 


\section{The aftermath}

It became clear quite shortly after the Parliament received the draft that certain parliamentarians and stake holders in Iceland would resist the draft becoming Iceland's Constitution. The draft was essentially shelved by the Althingi, where it remains to this date. Many reasons have been named for this failure: Was the draft too radical? Did it lack quality and professionalism? Did the public lose interest in this complex issue, with the imminent problem of making ends meet overtaking politically sublime topics such as constitution-writing? Did the powerful opposition, heavily linked to the 'owners' of Iceland's rich natural resources, simply manage to choke it? Was it a mistake of the Council to rewrite the constitution in its entirety, as opposed to merely amending some articles? Or is the old myth true which suggests that power corrupts and that democratically elected power-holders are unable, despite all promises, to give the power back to its rightful owner, the people?

It is not necessary to stipulate which, if any, of those suggestions are true for the purposes of this note. However, an important fact remains unhidden: the Icelandic voters have clearly articulated their desire for this draft to become the new constitution of Iceland: this was done in a non-binding national referendum on the constitutional proposal held on 20 October 2012. The referendum garnered substantial participation-half of the 235,000-strong electorate of Iceland participated-and secured a 2/3 approval of the draft as the basis of a new constitution. It remains to be seen whether Iceland's 'constitutional moment' has been missed, or whether the nation still finds itself in a process of constitutional transition.

\section{Conclusions}

Four years after the world's most inclusive constitution-writing process, Iceland still has its old Danish-based constitution. Media all over the world rushed to Iceland during the Constitutional Council's drafting process, admiring the process and the methods it employed. Communities in many different countries were inspired by this, and have consequently relied to some extent on a public participation model in their own transitions. The members of the Council, including myself, have travelled the world to explain how this could be done. The venues vary from small NGOs in basements in Amsterdam to the OECD annual conference in Paris. The story of Iceland's attempt to 'crowd-source' its 
constitution, at least to a degree, in the wake of huge financial crisis regularly fills the audience with a sense of inspiration and hope.

It is evident that new methods of constitutional transition are called for, as common problems like global warming, population growth, and resource depletion are likely to cause social, political, and economic upheavals in the years to come. If politicians choose to ignore democratic and civilized calls for change through legislation, the danger of more violent and rebellious outbursts are imminent. Iceland's constitutional transition was catalyzed by an economic crisis, rather than an environmental or a political one, but the economic cycles set in motion by the events of 2008 have not played themselves out yet. It is too early to say whether Iceland's transition is over. When the next financial disaster hits, Iceland will be affected like other places. The difference, however, of Iceland's situation will be that we have an alternative-a more sustainable, transparent, and fairer society mapped out in the draft of a new Constitution. Perhaps then we will find the courage to implement it and thereby see the world's first crowd-sourced constitution enter into force. 